\title{
BILL ATKIN: A FIERCE DEFENDER OF CHILDREN'S RIGHTS AND PROPONENT OF CHILD-FOCUSED LEGISLATION
}

\author{
Mark Henaghan* and Ruth Ballantyne**
}

\begin{abstract}
This article illustrates the different ways in which Professor Bill Atkin has shown where family law legislative reforms have fallen short in making the rights and well-being of children the paramount consideration in family law disputes, and properly taking account of children's views on matters that affect them. It examines Atkin's thought-provoking analysis of the introduction of the Care of Children Act 2004 and the changes made in recent years to the Child Support Act 1991, the Property (Relationships) Act 1976 and the Family Court system as a whole. The article also explores Atkin's approval of the amendments to the Crimes Act 1961 preventing parents from using physical discipline against their children for the purposes of correction. Overall, the article highlights Atkin's extensive contribution to family law and demonstrates what needs to be changed to ensure New Zealand family law and society becomes more child-focused in the future.
\end{abstract}

\section{INTRODUCTION}

Professor Bill Atkin has long argued that the rights and well-being of children should be the principal focus of family law. This strongly held view is at the centre of his wide-ranging and perceptive writing on family law affecting children. Atkin believes that it is unfortunate that issues often "turn out to be between adults, with the child the mere subject-matter". ${ }^{1}$ To this end, Atkin has been at the forefront of critical legislative analysis for several decades. He has been tireless in his call for family law legislation to better recognise the rights and views of children, and to ensure their welfare and best interests are truly the first and paramount consideration. This is particularly important work in a society where children have no individual political power of their own and are solely reliant on adults to improve their legal position.

* Professor and Dean of Law, Faculty of Law, University of Otago, Dunedin, New Zealand.

** Professional Practice Fellow, Faculty of Law, University of Otago, Dunedin, New Zealand. The authors wish to thank Summer Research Scholar Jonathon Yeldon for his invaluable research and editorial assistance with this article.

1 Bill Atkin "Children and Financial Aspects of Family Breakdown" (2002) BFLJ 85 at 85. 
This article illustrates the different ways in which Atkin has shown where family law legislative reforms have fallen short in making the rights and well-being of children the paramount consideration in family law disputes, and properly taking account of children's views on matters that affect them. This involves an examination of Atkin's thought-provoking analysis of the introduction of the Care of Children Act 2004 and the changes made in recent years to the Child Support Act 1991, the Property (Relationships) Act 1976 and the Family Court system as a whole. The article also explores Atkin's approval of the amendments to the Crimes Act 1961 preventing parents from using physical discipline against their children for the purposes of correction. Overall, the article highlights Atkin's extensive contribution to family law and demonstrates what needs to be changed to ensure New Zealand family law and society becomes more child-focused in the future.

\section{CARE OF CHILDREN ACT 2004}

The Care of Children Act 2004 has been in force for over a decade and is generally considered to be more child-focused than its predecessor, the Guardianship Act 1968. Indeed the stated purpose of the Care of Children Act 2004 is extremely child-focused: ${ }^{2}$

(1) The purpose of this Act is to-

(a) promote children's welfare and best interests, and facilitate their development, by helping to ensure that appropriate arrangements are in place for their guardianship and care; and

(b) recognise certain rights of children.

However, when the current Care of Children Act 2004 was first introduced to Parliament as the Care of Children Bill 2003, ${ }^{3}$ Atkin argued that the proposed legislation did "not go nearly as far as it could" in terms of providing sufficient legal recognition to the welfare, best interests and rights of children, especially in terms of children's views and their involvement in medical decision making. These issues are discussed in turn below.

\section{A Children's Views}

Clause 5 of the original Care of Children Bill required that "a child must be given a chance to express views on matters affecting the child", ${ }_{4}$ and that "any views the child expresses (either directly or through a representative) must be taken into account". ${ }^{5}$ Despite this proposed provision, which was a significant improvement upon the Guardianship Act 1968, Atkin advocated for

2 Care of Children Act 2004, s 3(1).

3 Care of Children Bill 2003 (54-1).

4 Care of Children Bill 2003 (54-1), cl 5(a). The wording of s 6(2)(a) of the current Care of Children Act 2004 is similar to $\mathrm{cl} 5$ (a) of the original Bill, with the only significant alteration being that the phrase "given a chance" was changed to "given reasonable opportunities".

5 Care of Children Bill (54-1), cl 5(b). The wording of s 6(2)(b) of the current Care of Children Act 2004 is identical to $\mathrm{cl}$ 5(b) of the original Bill. 
Parliament to give children's views a more central place in the legislation. ${ }^{6}$ Atkin noted that parents ultimately made decisions for children and that they could completely ignore their children's views when doing so, concluding that one therefore could "be forgiven for thinking that the Bill remain[ed] a largely adult-focused piece of legislation, rather than a child-centred one". ${ }^{7}$ Moreover, he noted that the Bill similarly did not "stop a Court from bypassing a child's views", made "no presumption in favour of a child's views", 8 and did not contain a mechanism "for ensuring that the child's views are genuinely heard". ${ }^{9}$

After hearing submissions on such issues by Atkin and others, the second incarnation of the Care of Children Bill did alter the exact wording used to increase the ability of children to be heard. ${ }^{10}$ The wording contained in $\mathrm{cl} 5$ (a) of the original Bill stating that children "must be given a chance" to express their views, ${ }^{11}$ was modified by the Select Committee and became children "must be given reasonable opportunities to express views". ${ }^{12}$ This alteration was a significant improvement because the use of the word "opportunities" implied that children would be given more than one chance to express their views. This wording endures to the current day, where s 6(2) of the current Care of Children Act 2004 requires a child to be "given reasonable opportunities to express views on matters affecting the child" by the court. ${ }^{13}$

However, Atkin's wider criticisms were not addressed, and the deficiencies that he identified in the Bill remained true after the passing of the Care of Children Act 2004. Parents and the court can still choose to bypass children's views (or may merely pay lip-service to the views held by children), especially when particularly young children are involved.

Such an approach was expressly permitted under the former Guardianship Act 1968 because s 23(2) of the Act identified a child's "age and maturity" as relevant factors in determining the weight to be given to a child's wishes. However, this was omitted from the Care of Children Act 2004 because it made it "too easy to dismiss young children's views" because the children were deemed to be "immature". ${ }^{14}$

6 Bill Atkin "The Care of Children Bill" [2004] NZLJ 44.

7 At 44

8 At 44 .

9 At 45 .

10 Care of Children Bill 2003 (54-2).

11 Care of Children Bill 2003 (54-1), cl 5(a).

12 Care of Children Bill 2003 (54-2), cl 5(a).

13 Care of Children Act 2004, s 6(2)(a).

14 Mark Henaghan "Case Note: Children's Views - Two Steps Forwards, One Step Backwards" (2006) 5 NZFLJ 154 at 154. 
Despite these reforms and the Care of Children Act 2004's improved focus on children's views, a disconnect remains between the wording and purpose of the legislation, and its application. For example, in $C v S$, Randerson $\mathbf{J}$ found that a child's age and maturity were still relevant in determining the weight to be given to their views. ${ }^{15}$ Further, he dismissed the failure to ask a four year old for her views as immaterial on the basis that these could not have reasonably affected the outcome of the case. The Court of Appeal agreed, saying: ${ }^{16}$

[T]he purpose of the exercise is associated with outcomes and not just process ... Despite the generality of the language of s 6, it must be applied in a sensible way. There is not much point in requiring a Court to ascertain the views of a child who is not capable of having or forming a view which is material. As to this, we see some flexibility in the expression "reasonable opportunities". We accept, as Randerson J did, that even a child as young as four could have and express views which might be material to her care arrangements and which therefore ought to be taken into account when decisions are being made about those arrangements. But a child of five (which is how old she now is) could hardly be expected to have and express views which would be material to the issue ... In those circumstances we concluded that it was not necessary for us to seek the views of the child in relation to the current application.

How can a court predetermine that a child's views are immaterial, when it has not even heard what that child's views are? Listening to children's views is not primarily about determining the outcome of the case. Rather, obtaining the child's views is "to show respect to the person who the decision is about". ${ }^{17}$ With that in mind, it is understandable why Atkin has critiqued the Care of Children Act 2004 for essentially allowing the child's views to "be completely ignored". ${ }^{18}$ Ignoring children does not respect their views, as the legislation was designed to do. ${ }^{19}$

\section{$B$ The Rights of Children}

\section{Children's rights generally}

Atkin also expressed concern that the stated purpose of the original Care of Children Bill did not contain any reference to the rights of the child, despite the fact that the explanatory note

$15 C v S$ [2006] 3 NZLR 420 (HC).

$16 C v S$ CA115/06, 18 October 2006 at [6] and [9].

17 Henaghan, above n 14, at 154.

18 Bill Atkin "Harmonising Family Law" (2006) 37 VUWLR 465 at 479. Atkin's prophetic words were borne out by a study of 120 Family Court decisions where children's views were completely omitted from the judgments in 28 per cent of all of the cases studied. See Antoinette Robinson and Mark Henaghan "Children: Heard But Not Listened To? An Analysis of Children's Views Under s 6 of the Care of Children Act 2004" (2011) 7 NZFLJ 39 at 41.

19 Care of Children Act 2004, s 3(2)(c). 
accompanying the Bill listed "ensuring a stronger focus on the rights of the child" as one of the primary objectives of the Bill. ${ }^{20}$ As Atkin stated: ${ }^{21}$

The "Purpose of this Act" as set out in cl 3 of the Bill does not mention the rights of the child at all ...

There is therefore a somewhat amazing gulf between the Explanatory Note and the official "purpose" of

the legislation. While respect for children's views may indirectly enhance their rights, those views can be ignored. Others make the decisions.

However, this issue was successfully resolved in the Bill as reported by the Select Committee, with the insertion of $\mathrm{cl} 3(1)(b) .{ }^{22}$ The express purpose of the legislation became to "promote children's welfare and best interests" and "recognise certain rights of children". This addition was as a direct result of submissions received by the Justice and Electoral Committee. As the Select Committee report states: ${ }^{23}$

We recommend an amendment to clause 3 to clarify that the bill recognises certain rights of children. Several submissions supported the addition of a reference to children's rights.

This illustrates the importance of academics and others making submissions to select committees about proposed legislation involving children in order to effect positive change.

\section{Children's rights and guardianship decisions}

Atkin has long advocated for New Zealand legislation involving children to directly address the 1985 decision of Gillick $v$ West Norfolk and Wisbech AHB from the United Kingdom, where the House of Lords found that children's powers to make their own decisions gradually increase as they mature, rather than arbitrarily occurring at a prescribed age. ${ }^{24}$ As Atkin said of Gillick: ${ }^{25}$

The majority of the House took the position that children gradually gain greater decision-making power as they grow older and the role of parents correspondingly wanes. Thus, children have the right to decide many things for themselves, depending on the nature of the issue and depending on their individual level of maturity.

20 Care of Children Bill (54-1) (explanatory note) at 2.

21 Atkin, above n 6, at 44.

22 Care of Children Bill (54-2).

23 Care of Children Bill (54-2) (select committee report) at 1.

24 Gillick $v$ West Norfolk and Wisbech AHA [1986] AC 112 (HL).

25 Atkin, above n 6, at 45. 
When the decision was released in 1985, Atkin argued that the case was applicable under New Zealand law and described it as a "historic" win for "the supporters of children's rights". ${ }^{26}$ Two years later, in January 1987, Atkin submitted that the Children and Young Persons Bill $1986^{27}$ (which ultimately became the Children, Young Persons, and Their Families Act 1989) "should take account of the House of Lords' decision in Gillick" ${ }^{28}$ Regrettably, Atkin's criticisms were not heard.

Atkin noted that the Care of Children Act 2004 was a further missed "opportunity to determine the place of Gillick in the law", ${ }^{29}$ despite the fact that the Act did subtly incorporate some related principles. As Atkin said: "There are a couple of modest signals in the description of the role of guardians that something of the Gillick philosophy has crept through." ${ }^{30}$ Atkin notes that s 16(1) of the Act states that it is the role of the guardian to contribute to a child's development and to determine "for or with the child, or [help] the child to determine, questions about important matters affecting the child". ${ }^{31}$ However, Atkin emphasises that the Act gives minors autonomy at "an arbitrary age", rather than due to "their level of maturity." ${ }^{32}$

To illustrate, Atkin notes that, with the exception of a young woman having the right to decide whether to have an abortion, the Care of Children Bill (which after some modification became the Care of Children Act 2004) gave children rights to consent or to refuse to consent to medical procedures based on "the arbitrary age limit of 16 and by the range of procedures specified". ${ }^{33}$ Those under the age of 16 are left in limbo, with no satisfactory guidelines as to how their competence to decide should be determined. In the end, decisions have to fall back on the test set out by Lord Scarman in Gillick - does the young person have "sufficient intelligence and understanding" to make the decision that they want to make ${ }^{34}$

It would have been more helpful if the Care of Children Act 2004 had incorporated some guidelines directly based on Gillick, such as a requirement for a prescribed sufficient level of

26 Bill Atkin "A Blow for the Rights of the Child: Mrs Gillick in the House of Lords" (1985) 1 FLB 35. See also Atkin, above n 6, at 45, where Atkin states that the decision "was a major strike in favour of children's rights".

27 Children and Young Persons Bill 1986 (97-1).

28 Bill Atkin "Submission to the Social Services Select Committee on the Children and Young Persons Bill $1986 "$ at 4.

29 Atkin, above n 18, at 479.

30 At 479 .

31 Care of Children Act 2004, s 16(1)(c).

32 Atkin, above n 18, at 479

33 Atkin, above n 6, at 45.

34 Gillick $v$ West Norfolk and Wisbech AHA, above n 24, at 114. 
understanding by the child. Clear guidelines would have assisted health professionals to determine when, and the degree to which, particular children should have the right to be more involved in important medical decisions. Such an approach would have been more in keeping with Atkin's strong view that "children's rights must be given a central place in any attempt at harmonising the law".35

\section{Children's right to bring proceedings}

Atkin has also critiqued the Care of Children Act 2004 for not giving children generally "any right to initiate proceedings", although he notes "there is an exception in section 31(2) which enables the child to ask to be placed under the guardianship of the court". ${ }^{36}$ Children over the age of 16 may also apply to a Family Court judge seeking review of their parent's decision about an important guardianship matter. ${ }^{37}$ However, Atkin questioned this arbitrary age requirement being placed on a child's ability to initiate such proceedings by $\mathrm{cl} 40$ of the original Care of Children Bill (and ultimately s 46C of the Care of Children Act 2004). ${ }^{38}$ Atkin questioned why a "mature 15-yearold" should not be able to seek a review of a parent's decision and why a child of any age should not be able to do so through a representative. ${ }^{39}$

Children can also technically seek leave from the court to bring proceedings granting them, for example, contact with a particular individual. ${ }^{40}$ However, as Atkin rightly pointed out when the Bill was originally proposed, why should children need leave to make an application to the Family Court "when the Bill is supposed to be about children". ${ }^{41}$ Sadly, this issue was not addressed and remains a problem today. ${ }^{42}$

\section{CHILD SUPPORT ACT 1991}

\section{A Adult Focused Legislation}

Atkin has also critiqued the Child Support Act 1991 for not being sufficiently child-focused. His main criticism is that the Act focuses on "the financial support of the child" and not "the best

35 Atkin, above n 18, at 479.

36 At 479

37 See Care of Children Bill (54-1), cl 40; and Care of Children Act 2004, s 46C.

38 Atkin, above $\mathrm{n} 6$, at 45 .

39 At 45 .

40 See Care of Children Bill (54-1), cl 43; and Care of Children Act 2004, s 47.

41 Atkin, above $\mathrm{n} 6$, at 45 .

42 The Care of Children Act 2004 does allow children to appeal some decisions as of right, but requires leave of the court to appeal other matters. See Care of Children Act 2004, s 143. It is important to note that the Act does not provide a legislative mechanism for an appeal brought by a child to be paid for. 
interests of the child". ${ }^{43} \mathrm{He}$ notes that although the Act "can impact on other family law situations and uses the Family Court for resolution of disputes", it is "largely isolated" from other areas of family law that affect children. ${ }^{44}$ Atkin explains that the legislation "is designed to make parents pay for their children, irrespective of the nature of the relationship between the payer and the child". ${ }^{45}$ He emphasises that the Act does not "[encourage] the financial parent to become a real parent" and does not provide incentive for "the custodian to encourage the absent parent to become active in the child's life". ${ }^{46}$ It is a purely revenue gathering statute focused on recouping money, rather than on the well-being of children.

Atkin has identified several aspects of the Child Support Act 1991 that fail to advance the child's welfare. Most significantly, he explains that the Child Support Act 1991 "does not incorporate the principle that the welfare and best interests of the child are to be paramount". ${ }^{47}$ Atkin notes that this omission is contrary to art 3 of the United Nations Convention on the Rights of the Child, which requires the child's best interests to be a primary consideration in all matters that affect children. ${ }^{48}$ He explains that the Court in $A v R^{49}$ even found that "there is no warrant, for importing, as a matter of principle, any 'welfare of the child' test into [the appointment of a step-parent under] $\mathrm{s}$ 99(4)(a)" ${ }^{50}$ Atkin emphasises that this ruling illustrates just "how out of step the Child Support Act 1991 is with fundamental family law and international principles". ${ }^{1}$ Further, he notes that the revisions made to the Child Support Act 1991 by the Child Support Amendment Bill $2011^{52}$ (which went on to become the Child Support Amendment Act 2013) did not remedy this problem as it failed to incorporate the welfare of the child as a primary consideration. ${ }^{53}$ The Child Support Act 1991 still does not require the welfare and best interests of the child to be a primary or paramount consideration.

43 Bill Atkin and Andrew Black "Child Support - Supporting Whom?" (1999) 30 VUWLR 221 at 221.

44 Bill Atkin "A trio of child support cases" (2008) 6 NZFLJ 107 at 107.

45 Atkin and Black, above n 43, at 228.

46 At 228

47 Atkin, above n 44, at 107

48 At 107. Convention on the Rights of the Child 1577 UNTS 3 (opened for signature 20 November 1989, entered into force 2 September 1990).

$49 A v R[1999]$ NZFLR 249 (HC).

50 Atkin, above n 44, at 107.

51 Atkin and Black, above n 43, at 228.

52 Child Support Amendment Bill 2011 (337-2).

53 Bill Atkin "Financial Support: Who Supports Whom?" in Bill Atkin and Mark Henaghan (eds) Family Law Policy in New Zealand (4th ed, LexisNexis, Wellington, 2013) 163 at 194. 
Atkin notes that the courts have raised questions about the relationship between financial support and the welfare of the child, despite the legislation failing to incorporate the welfare principle into the application of the Child Support Act 1991. He focuses on three cases that "bring into question the implementation of the child support scheme, but more fundamentally typify the extensive shortcomings of the legislation". ${ }^{54}$ One of these cases actually reads the welfare principle into the legislation. In $C v L$ [Child abduction] Allan J states: ${ }^{.5}$

The statutory regime is plainly based on the fundamental assumption that the welfare of children trumps

all else; whatever the shortcomings of the regime in its application from case to case, Parliament must

be presumed to have concluded that the welfare of children is paramount.

This finding aligns closely with Atkin's own steadfast view that child support cases need to focus on the impact the decision will have on the child, rather than merely on how best to collect revenue from the liable parent. ${ }^{56}$ This would be easier for the courts to achieve if the Child Support Act 1991 was amended to include the welfare principle.

Atkin believes that it is unfortunate that children do not have any right to the child support payment themselves. First, he emphasises that a child has no express power to obtain their own support, ${ }^{57}$ reasoning that this "perhaps illustrates the cynical view that [the Act] is more about adults and 'taxation without representation' than the welfare of children". 58 Atkin explains that this is another problem that the changes to the Child Support Act 1991 failed to address. ${ }^{59}$

Secondly, Atkin emphasises that "[t]here is no obligation on the custodian to spend the money on the child", taking this as further evidence that "the child support scheme is not child-focused, but adult-focused". ${ }^{60} \mathrm{He}$ observes that while the changes introduced a provision that enables a parent to directly make "qualifying" payments for goods and services that benefit the child, this is the only provision that ensures that the money is spent on the child. Further, Atkin explains that it will only apply in limited circumstances and the receiving parent is otherwise free to spend payments as they

54 Atkin, above $\mathrm{n} 44$, at 109 . In this article Atkin examines three decisions that illuminate the significant shortcomings of the Child Support Act 1991: C v L [Child abduction] [2008] NZFLR 960 (HC); Commissioner for Inland Revenue Department v DJP FC Tauranga FAM-2004-070-813, 21 July 2008; and Inland Revenue Department v C [2009] NZFLR 19 (FC).

$55 C v L$ [Child abduction], above $\mathrm{n}$ 54, at [47].

56 See Atkin, above n 44

57 Atkin, above n 1, at 89; and Atkin, above n 53, at 181.

58 Atkin, above n 53, at 181

59 At $194-195$.

60 Atkin, above n 1, at 89. 
wish. ${ }^{61}$ Ultimately, the child has no right to the money that concerns them, which only shows how legislation that is supposed to benefit children really is about adult considerations.

\section{B Recent Changes}

Atkin has long expressed the view that the child support system should be re-examined. ${ }^{62} \mathrm{He}$ has even suggested that "a complete overhaul of the Act may be required". ${ }^{63}$ Significant changes to the Child Support Act 1991 were put into motion by the Child Support Amendment Act 2013, the majority of which came into force in April 2015. ${ }^{64}$ However, following the introduction of the proposed changes (originally as the Child Support Amendment Bill 2011, which went on to become the Child Support Amendment Act 2013), Atkin recognised that the scheme still remained focused on "formulaic assessment, departures and enforcement". ${ }^{65} \mathrm{He}$ emphasised that while the reform was "the most significant" one to date, it was "not a complete overhaul" as he originally envisaged. ${ }^{66}$

The biggest change to the child support system was the introduction of a new formula for calculating the rate of child support to be paid. As Atkin explains: "The most momentous of the reforms in the Amendment Bill [was] the recalibration of the formula." 67 The new formula came into force on 1 April $2015,{ }^{68}$ and is significantly different to the formula contained in the old scheme.

The new formula considers the income of both parties for the first time. It calculates each parent's "child support income amount" using their taxable incomes as the basis for this. However, deductions are made for a living allowance, a dependent child allowance, and a "multi-group

61 Atkin, above n 53, at 196. This provision was included in the Child Support Amendment Act 2013. Section 38 of the Amendment Act will insert a new s 131 into the Child Support Act 1991 when that part of the Amendment Act comes into force on 1 April 2016.

62 Atkin and Black, above $\mathrm{n} 43$, at 236.

63 Atkin, above $\mathrm{n} 44$, at 109.

64 Sections 6, 31 and 32 of the Child Support Amendment Act 2013 (concerning transitional and savings provisions) came into force on 17 April 2013. Sections 18, 19, and 19A of the Amendment Act (concerning exemptions for long-term patients and prisoners, and individuals who earn additional income while otherwise exempt) came into force on 1 April 2014. The rest of pt 1 of the Amendment Act not already in force (including the new formula used for calculating child support) came into force on 1 April 2015. Part 2 of the Amendment Act (which concerns departures from formula assessment, collection, penalties and relief) will come into force on 1 April 2016. See Child Support Amendment Act 2013, s 2.

65 Atkin, above n 53, at 190

66 At 191

67 At 192

68 Child Support Amendment Act 2013, ss 2(3) and pt 1. 
allowance" for a parent who has had children with different partners. ${ }^{69}$ Then each parent's "income percentage" is: ${ }^{70}$

... derived by dividing the person's child support income amount (as determined under section 34) by

the sum of the child support income amounts, in relation to that child, of all the parents of the child.

This approach contrasts with the old model, which as Atkin explains, failed to acknowledge "that women are increasingly in the paid workforce" and "that fathers are more involved in caring for their children than in the past". ${ }^{71}$

Further, the new scheme better recognises shared parenting. Under the original Child Support Act 1991, a person other than the "principal provider" was only deemed to "share ongoing daily care of the child substantially equally" if they had care of the child for 40 per cent of the nights. ${ }^{72}$ However, recent changes introduced by the Child Support Amendment Act 2013 are far less onerous in that the notion of shared care has been expanded to include a lower proportion of a child's daily care. A liable parent who provides "at least $28 \%$ of ongoing daily care to the child" may not have to pay any child support if their income percentage is equal to their "care cost percentage". ${ }^{73}$ The Commissioner of Inland Revenue determines a parent's "care cost percentage" by consulting a table in sch $2 .{ }^{74}$ In determining a parent's "proportion of ongoing daily care", the Commissioner is to "rely on the content of any care order or agreement relating to a qualifying child". ${ }^{75}$

The new formula also takes into account the age of the children concerned. As Atkin explains: "The new formula recognises that a teenager costs more to feed and clothe than a younger child. Thus a liable parent pays more for a child aged 13 or over." ${ }^{16}$ It considers the "child expenditure amount" for a qualifying child, which is based on the age group of the child, as well as other

69 See s 34 of the Child Support Act 1991, as amended by s 12 of the Child Support Amendment Act 2013 on 1 April 2015.

70 See s 33 of the Child Support Act 1991, as amended by s 12 of the Child Support Amendment Act 2013 on 1 April 2015.

71 Atkin, above n 53, at 193.

72 See s 13 of the Child Support Act 1991 as at 7 December 2014 (not the latest version).

73 See s 31(1)(b) of the Child Support Act 1991, as amended by s 12 of the Child Support Amendment Act 2013 on 1 April 2015.

74 See s 16 of the Child Support Act 1991, as amended by s 10 of the Child Support Amendment Act 2013 on 1 April 2015.

75 See s 15(1) of the Child Support Act 1991, as amended by s 10 of the Child Support Amendment Act 2013 on 1 April 2015.

76 Atkin, above n 53, at 194. 
factors. ${ }^{77}$ Atkin explains that this aspect of the new formula aims to consider "the costs of bringing up children rather than the liable parent's income and the simple number of children." ${ }^{17}$

As well as the significant changes to the formula used for calculating the appropriate amount of child support to be paid, reforms that will be brought into force on 1 April 2016 by the Child Support Amendment Act 2013 will be more sympathetic to parents who incur penalties as a result of falling into arrears with child support payments. Atkin explains that the impending change "reduces the imposition of penalties and eases the circumstances when penalties can be written off". ${ }^{79} \mathrm{He}$ uses the future s 135FA of the Child Support Act 1991 as an example. ${ }^{80}$ This section will allow the Commissioner to "grant relief to the liable person" if they are satisfied that recovery of the penalties would "place the liable person in serious hardship" or "involve an inefficient use of the Commissioner's resources". ${ }^{81}$ According to Atkin, these changes may reduce the number of child support defaulters who "escape their situation by leaving the country, which helps neither the family nor the taxpayer". ${ }^{82}$

In terms of the totality of the reforms, Atkin reasoned that many of the changes introduced seemed fair and appropriate "when looked at individually". ${ }^{3}$ However, he has expressed understandable concern that, "when the overall picture is considered, the full impact of the changes is not so easy to discern". ${ }^{84}$ In particular, he criticised the new formula for being excessively complex. As Atkin rightly states: ${ }^{85}$

[T] he detailed mathematical formula ... is very hard to understand. Lawyers working in the field have had trouble making it work. Whether the general public will cope on their own is questionable. Given that the formula is linked to a computerised programme, this will simplify the actual calculation, but: (i) as a matter of principle, the law dealing with children should surely be reasonably accessible; and (ii) how fair the new formula will really be in practice is not easy to determine.

77 See s 30(2) of the Child Support Act 1991, as amended by s 12 of the Child Support Amendment Act 2013 on 1 April 2015.

78 Atkin, above n 53, at 194.

79 At 192

80 At 192

81 See s 135FA of the Child Support Act 1991, as will be amended by s 43 of the Child Support Amendment Act 2013 on 1 April 2016.

82 Atkin, above n 53, at 192

83 At 197

84 At 197.

85 At 192. 
The child support reforms also do not square with Atkin's focus on the rights and well-being of children as the primary consideration in all family law matters affecting children. Atkin emphasised that "the principal question to be asked" should really be "whether children will be better off, not only the children for whom child support is being paid but also the children for whom the liable parent is caring". ${ }^{86}$ If this is not the case, then as Atkin states, "a more fundamental re-think is required". ${ }^{87}$ This has long been Atkin's position. Prior to the introduction of the current reforms, he advocated for research to be undertaken in order to determine whether the scheme was "genuinely effective in helping children" as well as their caregivers. ${ }^{88}$ Despite the recent reforms to the Child Support Act 1991, many of the problems that Atkin has identified remain. Therefore it is more important than ever to consider how the child support scheme is actually affecting children. Atkin leads the charge in the call for the child support system to better account for the rights and wellbeing of children.

\title{
IV PROPERTY (RELATIONSHIPS) ACT 1976
}

Atkin explains that disputes concerning relationship property, like those concerning child support, are "typically between the parents" and are insufficiently child-focused. ${ }^{89} \mathrm{He}$ notes: "Children have few rights and their welfare and interests are only of marginal concern." 90 When Parliament made "significant changes" to the Matrimonial Property Act 1976 in 2001, changing its name to the Property (Relationships) Act 1976, Atkin was quick to highlight how the amendments related to the welfare of children. He notes that the reforms in the Property (Relationships) Act 1976 "contain only passing nods in the direction of children". 91

Section $1 \mathrm{M}$ of the Act requires a court "to provide for a just division of the relationship property ... while taking account of the interests of any children of the marriage or children of the civil union or children of the de facto relationship." 92 However, Atkin argues that the Act does not meet this purpose as children have few rights under its provisions. He explains that they are "not entitled to apply under the Act" and have no right to be heard. ${ }^{93}$ In addition, Atkin notes that while various

\author{
86 At 197. \\ 87 At 197. \\ 88 Atkin and Black, above $\mathrm{n} 43$, at 236. \\ 89 Atkin, above $\mathrm{n} 1$, at 85 . \\ 90 At 85 . \\ 91 At 85 . \\ 92 Property (Relationships) Act 1976, s 1M. \\ 93 Atkin, above $\mathrm{n} 1$, at 85 .
}


persons are entitled to be heard and appear as parties under s 37 of the Act, "it is doubtful whether children can take advantage of this". ${ }^{94}$

Moreover, children are not adequately represented in the relationship property division process. Atkin explains that the court "can appoint a lawyer to represent a child if such an appointment is thought necessary or desirable", but states: "One very rarely hears of such appointments being made in property disputes. "95 This is still an issue in recent times. As Professor Nicola Peart said in 2013, the power to appoint a lawyer for children is "seldom utilised". ${ }^{96}$ She explains that this situation is contrary to art 12(2) of the Convention on the Rights of the Child, which requires the child to be given an opportunity to be heard in proceedings affecting them. ${ }^{97}$

Ultimately, Atkin explains that "the obligation in s 26 to have regard to the children's interests has in reality little impact". ${ }^{98}$ Indeed the Court of Appeal has found that it cannot be used as a means of "simply reducing the proper entitlement of one spouse and increasing that of the other". 99 Atkin does note that "the interests of children may affect the actual implementation of the division of property" in terms of who is granted occupation of the family home. ${ }^{100}$ Under s $28 \mathrm{~A}$ of the Act, the court must "have particular regard to the need to provide a home for any minor or dependent child" in deciding whether or not to make an occupation order. However, Atkin explains that the section "does not, however, exclude other factors from the Court's consideration". ${ }^{101}$

Atkin acknowledges that there is an arguably "good reason" that proceedings under the Property (Relationships) Act 1976 are not significantly affected by the court's regard to the children's interests. ${ }^{102}$ This is because the Act is concerned with relationship property that is "owned by one or both of the parents", rather than "property owned by the children". ${ }^{103}$ Such relationship property "is divided between the parties on an equal basis" unless there are exceptional circumstances. ${ }^{104}$

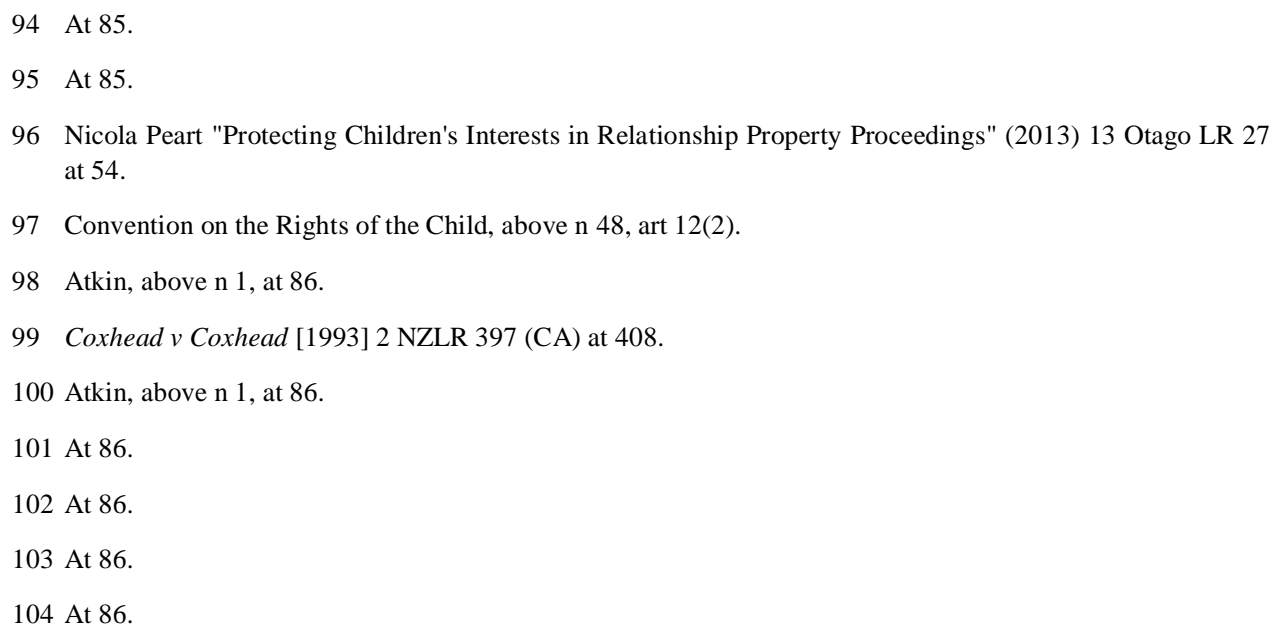


However, s 26 does contain a power that enables the court to settle property for the benefit of the children. Atkin explains that this rule does not in practice undermine the Act's rationale of equal sharing, noting that "the instances where s 26 has been used tend to be rather extreme and usually involve some misconduct". ${ }^{105}$ Indeed Peart notes that the courts only depart from equal sharing if they believe that the parties cannot be trusted "to care and provide for their children as best they can". 106

Despite some individual sections dealing specifically with children, the Property (Relationships) Act 1976 is almost entirely adult-focused. Atkin argues that it is another piece of legislation (alongside the Child Support Act 1991) that would benefit from research on the impact that it has on "children, families and individuals". ${ }^{107}$ There are important reasons to heed Atkin's call. Children have few rights under the Property (Relationships) Act 1976 and are not adequately represented. It is also problematic that financial considerations tend to overtake the needs of children to have a stable home to live in when their parents separate because occupation orders for the benefit of children are not prioritised by the Act. Atkin once again leads the charge in this important area of family law in his quest for legislation affecting children to be more child-focused.

\section{RECENT FAMILY COURT CHANGES}

Atkin was also vocal in his opposition to the changes to the family court system, originally proposed by the Family Court Proceedings Reform Bill in 2013. ${ }^{108}$ Atkin's primary concern was once again the adult-focused nature of the reforms and the lack of attention paid to the welfare of children. As Atkin said: "The law should be child-focused. This Bill is largely adult-focused and leaves children at risk." 109

\section{A Lawyer for Child}

Atkin was particularly troubled by the proposed changes to the appointments of lawyer for child (that later came into force on 31 March 2014 via the Care of Children Amendment Act (No 2)

105 At 86.

106 Peart, above $\mathrm{n} 96$, at 51.

107 Atkin, above n 1, at 90.

108 After some modification, this Bill ultimately became ten separate Amendment Acts (the majority of which came into force on 31 March 2014): the Care of Children Amendment Act (No 2) 2013; the Child Support Amendment Act (No 3) 2013; the Children, Young Persons, and Their Families Amendment Act 2013; the Domestic Violence Amendment Act 2013; the Family Courts Amendment Act 2013; the Family Dispute Resolution Act 2013; the Family Proceedings Amendment Act (No 2) 2013; the Legal Services Amendment Act (No 2) 2013; the Property (Relationships) Amendment Act (No 2) 2013; and the Protection of Personal and Property Rights Amendment Act 2013.

109 Bill Atkin "Submission to the Justice and Electoral Committee on the Family Court Proceedings Reform Bill" at 4. 
2013). The original wording of the Care of Children Act 2004 provided that the court "must" appoint a lawyer for the child in all cases involving day-to-day care or contact that seemed likely to result in a hearing "unless it [was] satisfied the appointment would serve no useful purpose".110 However, lawyer for child appointments are no longer mandatory. Section 7 of the Care of Children Act 2004 now provides that a lawyer for the child "may" only be appointed if the court "has concerns for the safety or well-being of the child" and "considers an appointment necessary"; 111 wording that Atkin argues is "problematic". 112

Atkin believes that these changes "weakened" the legal representation of children. ${ }^{113}$ Indeed, he said that the proposed changes in terms of when a lawyer for the child was to be appointed were "wrong" and would "deny children of their rights". ${ }^{114}$ Atkin questioned why the Family Court Proceedings Reform Bill made lawyer for child appointments discretionary, when mandatory appointment had been "regarded as one of the fine hallmarks of our law". ${ }^{115}$ This is a particularly short-sighted change that has more to do with attempting to save money, rather than adequately protecting the welfare of children involved in family law processes.

The insertion of s 7A(5) into the Care of Children Act 2004 also concerns Atkin because it prevents a lawyer from acting for a child unless that person has been appointed as a lawyer for the child by the court. As Atkin rightly states:116

This appears to say that children cannot instruct their own lawyers. Only a court-appointed lawyer can act for a child. This is highly objectionable and infringes children's rights. While children do not often have their own lawyers, they sometimes do and as a matter of principle, should not be denied this option.

Atkin also points out that this limitation prevents older children (16 and older), who wish to contest an important decision made by their parent or guardian, from obtaining legal representation to assist them in making an application to a Family Court judge under s 46C of the Care of Children Act 2004 unless the court has already appointed a lawyer to represent the child. ${ }^{117}$

110 See s 7 of the Care of Children Act 2013, as at 25 September 2013 (not the latest version).

111 Care of Children Act 2004, s 7.

112 Atkin, above n 109 at 7.

113 At 4

114 At 7.

115 At 7.

116 At 8.

117 At 9. 


\section{B Other Changes}

Atkin also expressed concern that children's views would be ignored if final parenting orders were able to be varied merely by a consent memorandum, rather than having to make a formal application to the court. Atkin explained that s 57 of the Care of Children Act 2004 (as then proposed) did not require the welfare or views of the children involved in the variation to be considered or taken into account by the court. Atkin argued that the section "should be amended to provide a mechanism for the child's views to be heard and for a statement about how the variation affects the child's welfare and best interests". ${ }^{118}$ Unfortunately the legislature chose to ignore Atkin's plea to make the section more appropriately child-focused and the provision was enacted unchanged on 31 March 2014. This was a real backwards step in the fight for better recognition of the importance of children's views and the paramountcy of their welfare in family law cases.

Atkin was also concerned that the new family dispute resolution (FDR) system (as then proposed) did not properly "provide for the involvement or representation of the child". ${ }^{119}$ As Atkin states: $:^{120}$

The second purpose of FDR is to ensure that the children's welfare and best interests are paramount.

How will this happen? The children are not represented. Who will speak for the children?

The new FDR system was enacted on 31 March 2014 and has now been up and running for some time. FDR providers do now have a duty to "assist the parties to reach an agreement on the resolution of those matters that best serves the welfare and best interests of all children involved in the dispute". ${ }^{121}$ This is a good change that clearly enhances children's welfare. However, it appears that Atkin's wider concerns are still valid because there are still no formal mechanisms to ensure children are properly heard and that their views are independently conveyed during the FDR process. Atkin's analysis highlights, that while the rhetoric of the changes was about making the process more child focused, ${ }^{122}$ the reality is quite different. Children remain largely unseen and unheard in the FDR process.

\section{CRIMES ACT 1961}

Atkin's strong children's rights stance has been used not just to critique proposed changes to legislation, but also to applaud positive legislative changes when they have occurred. To this end,

118 At 10

119 At 4.

120 At 12

121 Family Dispute Resolution Act 2013, s 11(2)(c).

122 Judith Collins "Reforms put children at heart of family law" (25 March 2014) New Zealand Government <www.beehive.govt.nz>. 
Atkin voiced his approval of the repeal of the defence of parental chastisement in s 59 of the Crimes Act 1961, calling it "a landmark in the development of the law". ${ }^{123}$ The former s 59 provided a defence to both civil and criminal proceedings if the force used was "reasonable" and "by way of correction". However, this section was replaced by a modified s 59, which generally removes corporal punishment and instead sets out the occasions where a parent is justified in using reasonable force, such as "preventing or minimising harm to the child or another person", ${ }^{24}$ "preventing the child from engaging or continuing to engage in offensive or disruptive behaviour", ${ }^{125}$ or "performing the normal daily tasks that are incidental to good care and parenting". ${ }^{126}$ For example, a parent would be justified in using reasonable force to restrain a child who was about to run across the road, or hit their sibling with a hammer. ${ }^{127}$ Atkin explains that "the whole tenor of the new section is about good parenting, not punishment". ${ }^{28}$

Atkin argues that such changes were overdue because allowing parents to use physical force against their children for the purposes of correction did not adequately recognise the rights of children. The use of physical parental discipline is also at odds with current societal values. As Atkin states: ${ }^{129}$

$[\mathrm{T}]$ he old defence of parental discipline was out of step with contemporary developments in the law. The repealed version of section 59 preserved an area of immunity for parents that largely ignored the child's welfare and safety.

The new provision means that the law now treats children more like adults in terms of offences like assault, in that an individual could be charged with assault if they smack a child for the purpose of correction, just as it would be if that individual smacked an adult in a similar fashion. However, children and adults are still not treated entirely equally by the law because s 59 allows some leeway in terms of the use of physical force towards children in particular circumstances that would not be permitted towards adults. In critiquing the reforms on this basis, Atkin suggests that it "may well have been better" to have abolished s 59 altogether. ${ }^{130}$ He states: ${ }^{131}$

123 Bill Atkin "Section 59 in its Legal Context: Intervening in Family Life" (2008) 12 Childrenz Issues 34 at 34.

124 Crimes Act 1961, s 59(1)(a).

125 Section 59(1)(c).

126 Section $59(1)(d)$.

127 See Atkin, above n 123, at 35.

128 At 35.

129 At 39.

130 At 35.

131 At 35. 
It is perhaps unfortunate up to a point that the law still enshrines special rules in the criminal code that single out the parent-child relationship. After all, one of the arguments for "repeal" was to remove the anomaly that what would be an offence if done to an adult escaped because it was done to a child by a parent.

Atkin argues that the law should treat children and adults the same "as far as these kinds of offences are concerned". ${ }^{132}$ This is a strong argument from a children's rights perspective, which is consistent with Atkin's stellar work in this important field.

\section{CONCLUSION}

Professor Bill Atkin has made an immense contribution to family law throughout his long and distinguished academic career. The consistent theme to Atkin's work is that the rights and views of children, and their welfare and best interests, should be central to all aspects of family law and family law legislation. Atkin is nothing if not persistent in his fight for children to be more involved in decisions about their lives. Atkin's observations are always thoughtful, well-measured and clearly illustrate what is really happening. Atkin has shown time and time again the myriad of ways New Zealand has failed to deliver legislation that fully recognises and enhances the rights, well-being and welfare of children.

Atkin knows more than most that the welfare of children is often unfortunately underrepresented in politics and their interests appear unlikely to win or lose votes. Therefore it is fundamentally important that academics like Atkin say the things that politicians do not wish to hear and often choose to ignore. In a future, more child-focused society, Atkin's work will prove to be prophetic. In the meantime, we applaud Atkin for his perseverance, and for his consistency in the fight for children's rights to be properly implemented within truly child-focused legislation, and for children's welfare and views to be respected as the foremost principle of family law. 
